International Journal of Instruction e-ISSN: 1308-1470 • www.e-iji.net

Article submission code: 20201019142837

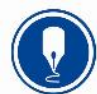

October $2021 \bullet$ Vol.14, No.4

p-ISSN: 1694-609X

pp. 1013-1032

Received: 19/10/2020

Revision: 17/05/202
Accepted: 12/06/2021

OnlineFirst: 20/09/2021

\title{
Competitiveness and Academic Excellence with Emerging Technologies: Methods for Assessing the Quality of University Education
}

\section{Artem Vasiliev}

Synergy University, Moscow, Russia, vasilievarte7@ rambler.ru

The article aims to examine theoretical and practical relationships between academic excellence and competitiveness in university education. The survey was conducted among university employees. Evaluation of each factor was carried out using the five-point Likert scale. The highest and statistically significant assessment was received for the following factors: the growth of graduates' salaries $(4.08,3.89,4.16)$, the number of foreign students $(4.01,4.44,4.56)$, the amount of extra-budgetary income of universities from various types of activities $(4.12,4.27$, $4.56)$, and the number of publications in indexed databases $(3.69,4.63,3.81)$. Several factors with the closest assessments among all the respondents were identified. Besides, very low estimates of the quality of state participation in maintaining competitiveness and academic excellence in universities were revealed. The paper unveiled how the general theoretical correlation of competitiveness and academic excellence is realized in the practice of educational systems' public administration. Furthermore, the study disclosed the indicators used to assess universities' activities in the context of competitiveness and academic excellence. The author believes that the use of competitiveness category in describing the purpose of the academic excellence program is justified. The study identified several significant factors in improving academic performance and competitiveness that affect the position of universities in Russia and developing countries in international rankings. The example of the Russian Academic Excellence Project demonstrated that the provision by the authorities of an artificial competitive advantage to specific universities negatively affects the level of competitiveness of other Russian universities.

Keywords: emerging technologies, excellence in higher education, performance indicators, quality of higher education, university competitiveness

\section{INTRODUCTION}

This study is devoted to a comparative analysis of recent academic excellence initiatives, undertaken by many European countries, as well as university activities aimed at improving a university's competitiveness in the higher education market (Secundo et al., 2017). The use of the competitiveness concept in relation to university's educational and scientific activities also involves placing a higher educational institution

Citation: Vasiliev, A. (2021). Competitiveness and academic excellence with emerging technologies: Methods for assessing the quality of university education. International Journal of Instruction, 14(4), 1013-1032. https://doi.org/10.29333/iji.2021.14458a 
(HEI) in the context of competition for limited solvent demand (Guerrero et al., 2016; Sitnicki, 2018).

Academic excellence demonstrated ability to perform, achieve, and/or excel in scholastic activities. It is a measurement of student's, teacher's or institution's progress and growth (Salmi, 2016a; Wood \& Su, 2017). Competitiveness in its most general form can be defined for research purposes as the ability to win competition in an educational setting (at a school, university level) (Secundo et al., 2017; Rubin, 2017b).

Initiatives of academic excellence in Europe and Asia (Paul \& Long, 2016), despite all their differences, significantly transform national educational systems in the direction of online learning, mobile learning (m-learning), making the digital environment an integral part of the learning process. At the same time, one of the goals of such initiatives may be a university's competitiveness in the context of emerging technologies in education. This issue arises in connection with the term "competitiveness" used by the Ministry of Science and Higher Education of the Russian Federation to describe goals of the Russian Academic Excellence Project 5-100. In this case, the scientific paradigm of university competitiveness is methodologically linked to world rankings and academic excellence, rather than Russian regional education systems.

This work reveals how the categories "competitiveness" and "academic excellence" of universities are theoretically and practically related, taking into account emerging technologies in learning. Besides, the research objective includes the investigation of how the general theoretical correlation of mentioned categories is realized in educational systems and whether the academic excellence initiative can be used to identify competitive universities. The considered issues have been of practical importance in formulating the goals of academic excellence programs and educational rankings as well as in choosing targets for universities seeking to improve their competitiveness (Fumasoli, 2017; Visvizi, Lytras \& Daniela, 2018; Komotar, 2020). Both categories include an understanding of the potential of using the digital environment, online learning, and m-learning in various forms (Naser, Al Shobaki \& Amuna, 2016; Visvizi, Lytras \& Daniela, 2018). In addition to theoretical studies and analysis of international experience, the paper presents a survey of teachers, researchers, and administrative workers of Russian HEIs to review various factors' significance for competitiveness and academic excellence.

Emerging technologies in learning are considered by almost all researchers and university development programs as a basic component of competitiveness (Thurman \& Efimova, 2014; Vasilev, 2017; Secundo et al., 2017; Redondo et al., 2018; Parakhina, Godina, Boris \& Ushvitsky, 2017; Maket, 2017; Musselin, 2018). Digital competence of teachers and students in universities is growing all the time. A university's ability to provide emerging technologies is critical to compete globally (Benneworth et al., 2017; Gourlay \& Stevenson, 2017; Antony, 2018; Beerkens, 2018).

In most countries, academic excellence is asserted through integration into international standards and teaching methods (Wood \& Su, 2017; Tasopoulou \& Tsiotras, 2017; Secundo et al., 2017). Most emerging technologies today are the standard for university 
programs, but in most cases are not included in documented standards. This creates difficulties for the implementation of these technologies in countries where state support for higher education is based on the implementation of documented international education standards (Avralev \& Efimova, 2014; Antony, 2018; Beerkens, 2018). The best practices tend to be quickly introduced due to international competition and the development of the online learning segment (Guilbault, 2016; Salmi, 2016b). However, the Russian experience is much different. The Russian system of higher education is characterized by a deep level of regulation, the predominant role of the state in educational relations, state educational standards, accreditation, and monitoring of universities' effectiveness.

In order to meet the purposes of the article, the following tasks are to be solved:

- compare the theoretical content of "competitiveness" and "academic excellence" in higher education;

- compare the officially declared goals of various European programs on academic excellence in the context of universities' intention to increase their competitiveness;

- disclose the indicators used in accordance with the Russian Academic Excellence Project to assess universities' activities in terms of academic excellence and competitiveness.

University competitiveness is the ability to withstand competition with other HEIs and contest with others for resources and education quality. Among the most important resources that determine competitiveness are mobile and online learning programs, as well as the use of modern collaborative technologies (Guilbault, 2016; Redondo et al., 2018). A university's academic excellence is a fact of achievement and demonstration of the best performance indicators by this university. This excellence testifies to a university's leadership in a particular aspect or in several aspects (quality of education, the effectiveness of scientific research, publication activity) (Guerrero, Urbano \& Fayolle, 2016; Maket, 2017). As a concept, university competitiveness has less content and more volume than academic excellence. Competitiveness involves the use of digital environment resources as one of the significant factors. In the field of higher education, the combination of competitiveness and academic excellence was first paid attention to in the process of development of the world-class university (WCU) academic status (Salmi, 2016b).

WCUs are leaders in the global educational space. The competition theory denotes that leadership is only one of the possible aspects that ensure competitiveness. In addition to leaders, in any educational space (global, national, regional), one can also identify candidates for leadership and leaders' followers (Rubin, 2017a). The very definition of this class of educational institutions indicates the importance of online learning technologies for them as a means of attracting students and providing a wider range of services. HEI can be competitive in the local education market, although not achieve excellent results, for example, in publishing activity. However, university's excellent results imply that it has competitive advantages, strategy, and a sufficient competitiveness level (Lukovics \& Zuti, 2013; Satsyk, 2018). 
The identification of the competitiveness and academic excellence of HEIs is based on various comparison practices. To determine the most competitive university, researchers often use the market matching strategy. HEI is recognized competitive if its educational and scientific activities are demanded by society and business to a greater extent than other universities. Each competitive university independently determines the source of its competitive advantage, develops and implements a competitive strategy, segments markets, and differentiates services. Among these factors, emerging technologies play a huge role, which has not yet been studied by researchers in terms of their impact on university competitiveness. Hence, the survival of HEI in the education market can be ensured by a wide variety of practices.

Academic excellence initiatives (as a way to identify the best universities) that ignore the realities of the competitive environment of national and international higher education systems risk becoming an administrative command mechanism for identifying "academically excellent" universities and allocating targeted funding (Rubin, 2017a; Budzinskaya, 2018). In this case, there is a threat that market competition mechanism and the administrative command mechanism for choosing the best university will turn out to be two different ways of distributing the educational system resources.

\section{Literature Review}

\section{Approaches to academic competitiveness}

These days, the competitive approach is widely applied to higher education (Guilbault, 2016; Musselin, 2018; Redondo et al., 2018). Unfortunately, they pay too little attention to emerging technologies as a component of competitiveness, although they point to their importance. As a consequence, many authors have emphasized the need to adapt pure market mechanisms to universities (Sitnicki, 2018; Visvizi et al., 2018). The emergence of private HEIs and the need to ensure the educational value and support the public sector have pushed universities' management to look for ways through which they can create the educational value as well as test and keep it in an institution (Maket, 2017).

Pucciarelli and Kaplan (2016) have identified three core challenges that HEIs face and that have fundamental implications for research and practice: (1) the need to enhance prestige and market share; (2) the need to embrace an entrepreneurial mindset; and (3) the need to expand interactions and value co-creation with key stakeholders.

Guerrero, Urbano, and Fayolle (2016) emphasize that in modern socioeconomic scenarios, the role of entrepreneurial universities is to generate and transfer knowledge, as well as create entrepreneurial thinking and actions.

Budzinskaya (2018) denotes that, at the current technological development stage, universities have ceased to be only transfers of knowledge, but also units facilitating innovations. Among the central criteria for assessing universities' competitiveness are the commercialization of developments and the export of educational services that are closely related to the digital shift of most educational processes. Therefore, the role of online learning for competitiveness is recognized as critical. Meanwhile, many 
researchers indicate that in addition to conducting research, HEIs acquire one more essential function - transfer of knowledge and technology. This transfer is almost universally based on mobile communications and online technology. Accordingly, a university's involvement in business processes, training of specialists, implementation of targeted research programs, etc., becomes critical for an institution's competitiveness (Secundo et al., 2017; French, 2017).

\section{Measures and factors of competitiveness}

Many studies provide strong evidence that regional competitiveness and university spillovers are strong complements in fostering innovation activity of entrepreneurial firms (Guerrero et al., 2016; Lukovics \& Zuti, 2013). Parakhina et al. (2017) claim that the most critical issue of the competitiveness of Russian universities is the lack of strategic flexibility. Besides, nowadays, there is a structural nature of the management crisis affecting the whole system of university education.

A vast number of scientific works focus on specific factors that ensure the university competitiveness or tools aimed at its enhancement rather than the competitiveness itself. Among such factors are benchmarking academic excellence (Ruben \& Gigliotti, 2019; Tasopoulou \& Tsiotras, 2017), entrepreneurship (Nabi et al., 2017), knowledge management (Naser et al., 2016), educational innovation, especially in the field of online learning technologies (Visvizi et al., 2018), reputation and brand (HemsleyBrown et al., 2016).

Russian researchers apply a competitive approach to relations in higher education under the current educational legislation (Vasilev, 2017) and the provisions of the constructive competition theory, which distinguishes competition for resources, results, and excellence of educational processes (Rubin, 2017a; 2017b).

\section{Approaches to academic excellence}

The definitions of excellence are located within social, economic, and political contexts and are assumed by many as a contested concept that is historically and situationally contingent (Wood \& Su, 2017). Analytic Quality Glossary defines excellence as exhibiting characteristics that are very good and, implicitly, not achievable by all (Harvey, 2020). Initially, an excellence-based approach was applied to the management of commercial organizations (The EFQM Model, 2020). However, in 2012, the European Network for Quality Assurance in Higher Education initiated a working group on excellence, aiming to increase knowledge on this concept, particularly in relation to the development of procedures for university accreditation and assessing the higher education quality (Fumasoli, 2017; Tatiana, 2017). Various approaches to excellence serve to illustrate the multi-dimensional aspects of this notion. In the context of European programs on academic excellence, the issue of gender equality in the academic field plays a significant role (Yousaf \& Schmiede, 2017). Among other notions are the ease of access to education and the implementation of an individual rhythm of learning, which are provided by m-learning and online learning. Excellence can be identified at the level of an institution, faculty, department, or staff and can be applied in the context of the many different roles and functions of HEIs (Komotar, 
2020). Excellence is connected with management and service delivery, especially online services in modern times, the experience of staff and students, or the outputs from study and research. What is clear is that, for the modern higher education system, excellence is an expectation and a goal (Beerkens, 2018).

At first, the concept of academic excellence was applied exclusively to teaching and learning aspects. The developed methods of educational accreditation procedures and assessment of the quality of education made it possible to distinguish excellence in teaching and excellence in student performance. In 2007, researchers from the Center for Higher Education Research and Information conducted a literature review, considering excellence in teaching and learning (Wood \& Su, 2017). Later, as part of the Higher Education Academy research series, Gourlay and Stevenson (2017) used the same approaches and conducted another review, examining excellence in teaching in HEIs.

\section{World university rankings}

With the development of World University Rankings, excellence has become applicable to universities' research activities, giving way for the creation of excellence in research frameworks (for example, the UK Research Excellence Framework). Since then, many scholars have described the best practices for research universities. The most relevant feature of such practices is the web integration of all educational subjects, the availability of all online resources and the active commercial online activities of a university. For instance, Paul and Long have examined the recent experience of 11 HEIs in nine countries that have grappled with the challenges of building successful research institutions under challenging circumstances (Paul \& Long, 2016).

Describing the activity of WCUs, Salmi (2016a) states that the superior results of these institutions (highly sought graduates, leading-edge research, and technology transfer) can essentially be attributed to three complementary sets of factors: (a) a high concentration of talent (faculty and students), (b) abundant resources to offer a rich learning offline and online environment and to conduct advanced research, and (c) favorable governance features that encourage strategic vision, innovation, and flexibility and that enable institutions to make decisions and to manage resources without being encumbered by bureaucracy. Froumin and Lisyutkin (2018) have found that governments aimed at the establishment of the WCUs increase their interference in higher education systems and even in the operation of educational institutions. Consequently, the matter of the changing autonomy of HEIs participating in excellence initiatives arises.

Many studies provide a comprehensive amount of comparative information on European academic excellence programs, focusing on public funding mechanisms that are directed at raising performance of certain HEIs to an "excellent" level (French, 2017). Based on their analysis, researchers recommend avoiding direct links between the academic excellence scheme and international ratings as the methodology and measurement criteria of the latter might differ (Antony, 2018). An important generalization of the use of benchmarking for independent evaluation is given in the work of Tasopoulou and 
Tsiotras. They indicate that the benchmark is unrelated to the specific conditions or educational system of a particular country, and can be used independently within the methodology of a country or an educational institution (Tasopoulou \& Tsiotras, 2017).

\section{Russian experience}

After the launch of the Russian Academic Excellence Project 5-100 (Government Decree No. 211 of 16 March 2013 On Measures of Government Support for Leading Russian Universities to Increase their Competitiveness Among the World's Leading Research and Education centers), Russian researchers have also begun to study and evaluate the competitiveness of Russian universities. Though, such examinations were based solely on the World University Rankings (Avralev \& Efimova, 2014; Bragin et al., 2014; Thurman \& Efimova, 2014).

These days, Project 5-100 results are considered controversial. As Project 5-100 ignores potential national and local contributions, there are academic and expert discussions arguing that the implementation of excellence initiatives is, in large degree, irrelevant to national and local challenges (Froumin \& Lisyutkin, 2018; Benneworth et al., 2017). However, Project 5-100 participants continue building new laboratories and increasing publication activity. As a consequence, the number of their publications in Scopus has more than tripled - from 19,000 in 2010-2012 to 63,500 in 2014-2016. After analyzing the available aforementioned data from Scopus, Russian researchers have developed the following strategies to promote articles by Russian researchers in Scopus and improve the academic ratings for Russian HEIs:

1. Conferences strategy, related to Scopus indexation of reports from international virtual conferences;

2. Headhunted author strategy, connected with the attraction of prominent authors;

3. Predatory journals strategy, attributed to publications in journals with a doubtful reputation (Guskov et al., 2018).

\section{METHOD}

In order to obtain an accurate assessment of the significance of various competitiveness and academic excellence factors, a survey was conducted among three social groups that represent the basic human potential of universities - teachers, researchers, and administrators. Only representatives of the highest level of the university administration were involved in the participation, a head of a department - University Professors who have also undertaken the role of Rectors, Vice-rectors, Deans, and Heads of Departments and Laboratories. Considering that the same person can often participate in teaching, research, and administrative activities, the selection was carried out using a double definition. A participant could independently decide on which of the groups he/she belongs to, taking into account his/her prevailing involvement in one of the mentioned areas. Though, the study involved only those individuals whose personal choice of the activity and real occupation coincided. The final sample engaged 142 teachers, 121 researchers, and 98 administrative workers from 172 universities of the Russian Federation (all federal subjects of Russia were covered). 
The examination was conducted by sending electronic invitations and questionnaires to a large number of people randomly selected from databases and public Internet resources of Russian universities. Before the start of the study, all participants confirmed their participation and completion of the questionnaires on the condition of guaranteeing anonymity. Thus, the sample meets the described conditions. All the involved were assigned a unique identifier and asked to use a second e-mail when sending out a completed questionnaire. Hence, on the one hand, unambiguous identification of a research participant as a higher education worker was achieved, and, on the other, the complete confidentiality of individual data was assured.

The representativeness of the research sample was calculated on the basis of the total number of teachers in the universities of the Russian Federation for the 2018-2019 academic years according to the State Statistics Committee of the Russian Federation (Gazizova et al., 2016). With the accepted confidence level of 95\%, the statistical sampling error does not exceed 1.03. Given the research sample representativeness, the research results can (with a high degree of probability) be extended to the entire research population.

To determine the factors of competitiveness and academic excellence, 361 study participants were asked to select those factors that seemed the most important to them. The primary list of such factors was based on a preliminary study of the research subject; however, all the involved could also offer their own factors for the examination. The final questionnaire included factors that were identified as significant by more than $80 \%$ of respondents.

Thus, the first step of the study was to obtain a list of significant factors, based on which a questionnaire was created, in which the factors indicated and collected from the respondents could be assessed using the Likert scale. To test the test-retest reliability of this questionnaire, two consecutive surveys were conducted with a difference of two weeks with a request to evaluate the significant factors included in the test scale. The correlation of the results was tested using the Pearson correlation coefficient. Internal consistency was checked using the Cronbach alpha coefficient. Test-retest reliability (r) equals 0.81 , internal consistency $(\alpha)=0.87$. The expert validity of the test is ensured by the fact that it is based on factors selected by the participants themselves, which ensures that the test reflects the targeted categories. Construct validity is ensured by a common understanding of the terms and categories used in the test by all test participants. The empirical validity of the test will be further clarified when tested on other groups.

Evaluation of each factor was performed through the five-point Likert scale, where 5 indicated the critical significance, and 0 - the absence of any significance for a respondent. Rating 3 (middle of the scale) identified that a factor was important, but did not give much value to a participant.

The proposed factors were structured as follows: the first four (1-4 in Table 1) related to the competitiveness formation; the following six (5-10 in Table 1) related to the development of academic excellence; and the last three (11-13 in Table 1) were included to obtain an assessment of the government involvement in these processes. 
Table 1

Structure of competitiveness and academic excellence factors for universities

\begin{tabular}{|c|c|}
\hline \multirow{4}{*}{ Competitiveness formation } & 1. Share of graduates employed after graduation \\
\hline & 2. Average grades of graduates \\
\hline & 3. Graduates' salary \\
\hline & 4. Number of agreements \\
\hline \multirow{6}{*}{$\begin{array}{l}\text { Development of academic } \\
\text { excellence }\end{array}$} & 5. Number of open online courses on international platforms \\
\hline & 6. Scope of research \\
\hline & 7. Number of international teachers \\
\hline & 8. Number of international students \\
\hline & 9. Citation rate \\
\hline & 10. Database publications \\
\hline \multirow{3}{*}{$\begin{array}{l}\text { Assessment of the } \\
\text { government involvement in } \\
\text { these processes }\end{array}$} & 11. Government accreditation \\
\hline & 12. Government financing \\
\hline & 13. Extrabudgetary revenue share \\
\hline
\end{tabular}

The objective of the current research was to assess the significance of the various factors for achieving competitiveness and academic excellence in the context of emerging technologies in learning. This will allow a more profound study of the theoretical and methodological differences in approaches to evaluating and managing university's competitiveness and academic excellence initiatives that would rely on the existing practice.

The limitation of the research lies in the fact that it did not cover a sufficiently large number of participants in all regions of the Russian Federation and, therefore, should be supplemented by similar studies in the future. The issue of a subjective assessment of participants during the examination was partially tackled by the significant sample size and its social structure. In the future, it is still advisable to strengthen the obtained information by research with statistical data on real results achieved by Russian universities.

\section{FINDINGS}

The presented below Table 2 and Figure 1 display the results of the conducted survey. The main difference is that Table 1 gives the values of standard deviation for each of the averaged estimates, while Figure 1 is only a visualization of the presented data. The displayed information contributes to an adequate assessment of the relevance of evaluating specific factors in each respondent group. Besides, it enables obtaining an idea about the degree of participants' unanimity toward the evaluation. The more unanimous the estimate, the less it differs from the average value.

As can be seen from Table 2, estimates of several factors are relevant and independent of each other within each group's assessment. In parallel, there is a slight discrepancy in maximum and minimum estimates, which suggests that all the criteria remain significant for most participants. The only exception is the very low estimate of the importance of state accreditation and university funding as a factor in achieving competitiveness and academic excellence among teachers and researchers (2.56 and 1.98 for accreditation and 2.01 and 2.21 for financing, respectively). In the same manner, administrators rated 
the importance of the number of open online courses on international platforms (2.46), though highly evaluated the significance of the above two criteria (3.99 and 3.88, respectively).

Table 2

Importance of competitiveness and academic excellence factors for universities

\begin{tabular}{|c|c|c|c|c|c|c|}
\hline & \multicolumn{2}{|l|}{ Teachers } & \multicolumn{2}{|c|}{ Researchers } & \multicolumn{2}{|c|}{ Administrators } \\
\hline & Average & St. Dev. & Average & St. Dev. & Average & St. Dev. \\
\hline $\begin{array}{l}\text { 1. Share of graduates } \\
\text { employed after } \\
\text { graduation }\end{array}$ & 3.93 & 0.89 & 3.51 & 0.34 & 4.35 & 0.33 \\
\hline $\begin{array}{l}\text { 2. Graduates' average } \\
\text { grades }\end{array}$ & 4.03 & 0.48 & 3.84 & 0.74 & 4.36 & 0.44 \\
\hline $\begin{array}{l}\text { 3. Graduates' salary } \\
\text { growth }\end{array}$ & 4.08 & 0.44 & 3.89 & 0.86 & 4.16 & 0.46 \\
\hline $\begin{array}{l}\text { 4. Number of } \\
\text { agreements }\end{array}$ & 3.24 & 0.36 & 4.75 & 0.49 & 4.88 & 0.42 \\
\hline $\begin{array}{l}\text { 5. Number of open } \\
\text { online courses on } \\
\text { international platforms }\end{array}$ & 4.05 & 0.54 & 3.56 & 0.86 & 2.46 & 0.89 \\
\hline 6. Scope of research & 3.99 & 0.81 & 4.89 & 0.16 & 3.79 & 0.46 \\
\hline $\begin{array}{l}\text { 7. Number of } \\
\text { international teachers }\end{array}$ & 3.57 & 0.63 & 4.86 & 0.86 & 4.09 & 0.42 \\
\hline $\begin{array}{l}\text { 8. Number of } \\
\text { international students }\end{array}$ & 4.01 & 0.71 & 4.41 & 0.46 & 4.56 & 0.52 \\
\hline 9. Citation rate & 3.82 & 0.61 & 4.52 & 0.45 & 3.59 & 0.48 \\
\hline $\begin{array}{l}\text { 10. Database } \\
\text { publications }\end{array}$ & 3.69 & 0.89 & 4.63 & 0.44 & 3.81 & 0.68 \\
\hline $\begin{array}{l}\text { 11. Government } \\
\text { accreditation }\end{array}$ & 2.56 & 0.67 & 1.98 & 0.32 & 3.99 & 0.56 \\
\hline $\begin{array}{l}\text { 12. Government } \\
\text { financing }\end{array}$ & 2.01 & 0.51 & 2.21 & 0.61 & 3.89 & 0.28 \\
\hline $\begin{array}{l}\text { 13. Extrabudgetary } \\
\text { revenue share }\end{array}$ & 4.12 & 0.57 & 4.27 & 0.13 & 4.56 & 0.26 \\
\hline
\end{tabular}

From this and other discrepancies in assessments, it becomes evident that the evaluation of the significance of various factors in university development varies markedly among different groups of participants. At the same time, Figure 1 depicts several factors, estimates of which are similar among all respondents: graduates' salaries $(4.08,3.89$, 4.16, respectively), the number of international students at a university $(4.01,4.44,4.56$, respectively), the number of publications in indexed databases $(3.69,4.63,3.81)$, and the amount of extrabudgetary income of universities from their scientific and other activities (4.12, 4.27 and 4.56, respectively).

Furthermore, the estimates of all the competitiveness factors, to a great extent, are logically related and lie within a narrow range of ratings (from 3.24 to 4.88 - rating range is 1.64). The second group of academic excellence factors occupies a broader range of assessments (from 2.46 to 4.89 (rating range corresponds to 2.43)). What is 
notable, the estimates of several factors from this group often change to the opposite. Such dramatic shifts indicate that university competitiveness and academic excellence are not identical and denote different but interdependent phenomena, recognized by the participants of the higher education development process.

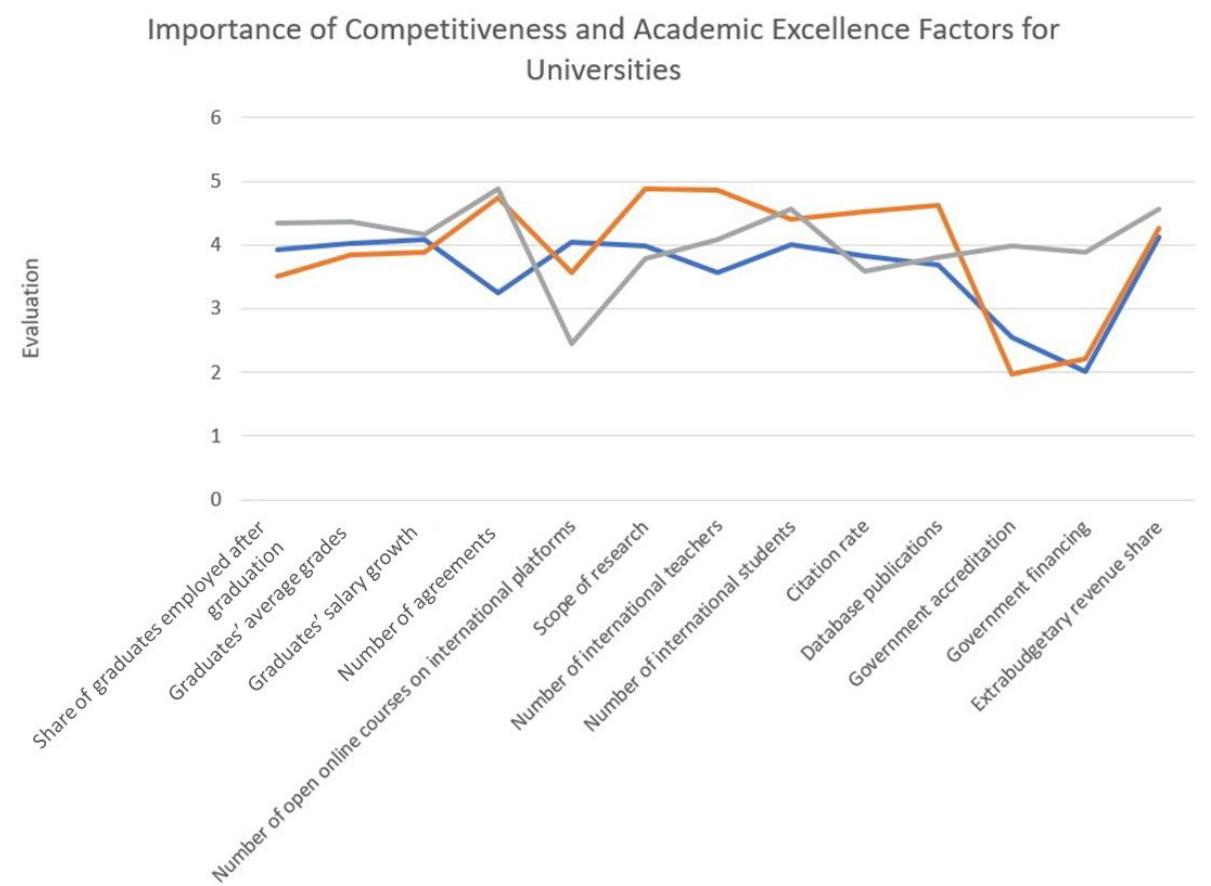

Figure 1

Importance of competitiveness and academic excellence factors for universities

In general, data from Table 2 and Figure 1 allow the formulation of conclusions that the concept of university competitiveness is perceived quite uniformly. The corresponding factors received close estimates from all the survey participants. Concurrently, academic excellence factors are much more controversial, and there was no consensus on their assessment.

The obtained results can be practically applied when implementing decisions to increase the HEI position in international rankings, improve its competitiveness, or achieve academic excellence in any educational field. Adequate assessment of the main operating factors and other countries' experiences will enable many universities to act more effectively toward becoming one of the WCUs.

To have a fuller idea of the question under study and compare the results with world practice, one should consider the officially declared goals of various European academic excellence programs in the context of HEI's activities aimed at competitiveness improvement. European Academic Excellence Initiatives are official programs designed 
for targeted funding of universities and colleges by European governments. Given the diversity of education systems in Europe, such funding mechanisms differ significantly in various European countries (Secundo et al., 2017). Nevertheless, they have more in common than one may believe. Unlike basic state funding, in the framework of European Academic Excellence Initiatives, finances are distributed on a competitive basis only to the best HEIs to solve specific tasks of national educational systems.

The most common goals of European Academic Excellence Initiatives are as follows:

- Enhancing the competitiveness of a system's research landscape in the context of international competition;

- $\quad$ Restructuring the higher education/research landscape;

- Enhancing the international visibility of the research system

- Improving the system and related quality objectives;

- Internationalization;

- Improving HEIs' positions in international rankings.

From the point of view of university management, the increase of a HEI's competitiveness should take into account ensuring the effectiveness of its functioning in a competitive environment. For representatives of state education management bodies, it is essential to enhance the competitiveness of the national higher education system compared to the educational systems of other countries. Simultaneously, the higher education administration leaders are guided by WCUs, which are beacons of efficiency and competitiveness in higher education (Salmi, 2016a). From the perspective of the education management bodies, there is a transition from stimulating the development of all HEIs to targeted financing of top universities.

\section{DISCUSSION}

Current European Academic Excellence Initiatives intend not to increase the regional competitiveness of all universities in the national educational system, but to improve the international competitiveness of particular HEIs. Therefore, the use of the competitiveness concept in describing the goals of academic excellence initiatives can only be considered partially justified. In order to achieve the goals of competitiveness, as experience shows, universities focus primarily on such factors as attracting foreign students, increasing income from activities and scientific developments, etc. (Guerrero et al., 2016).

Instead of government measures that create development incentives and ensure equal competition conditions for all universities in regional and national markets, most European countries provide targeted state funding of certain universities. This practice also directly intersects with the competitiveness factor identified in the present study the availability of external allocations and government support. Therefore, it is needless to say that academia is concerned that the educational authorities present universities in the national and regional markets as out-of-competition HEIs. All of them are centers for the development of emerging educational technologies, primarily online and $\mathrm{m}$ learning (Salmi, 2016a; Sitnicki, 2018). 
The Russian government uncritically perceived the indicated inconsistency of approaches during the formation of the Russian Academic Excellence Project, which is reflected in its regulatory documents. As a result, by decree of the President of the Russian Federation No. 599 On Measures to Implement the National Social Policy in Education and Science of 7 May 2012, the task was set to have at least five Russian universities in the top 100 of the world's leading HEIs according to international rankings by 2020. To achieve this goal, the government launched Project 5-100 intended to provide state support for the best universities of the Russian Federation and increase their competitiveness among world research and educational centers.

In just seven years (2014-2020), the government of Russia spent more than \$1.6 billion in the form of subsidies to increase the competitiveness of 21 leading Russian HEIs. However, according to world ratings, by 2020 , Russian universities were not included in the top 100 list. Thus, another formal goal set by the Decree of the President of Russia was not achieved. In spite of this fact, the results of the project are deemed positive since, as of 2020, the government allocated and distributed more than \$249 million among 21 HEIs (Project 5-100, 2020). Comparing with European experience, the use of the competitiveness category in describing the goals and objectives of the Russian Academic Excellence Project is partially justified since it is directed at increasing universities' global competitiveness rather than local. For this reason, only the best HEIs have the opportunity to improve their performance indicators.

In 2019, out of the 1,264 universities in Russia, there were 920 state and public and 344 private HEIs (72.8\% and 27.2\%, respectively) (Miccedu, 2020). There were 4,174,944 higher education students at Russian universities as of 2019, of which $91.3 \%$ studied at state and public HEIs and only $8.7 \%$ - at private ones. Furthermore, 1,941,901 students occupied state-funded places $(46.5 \%)$. In such a way, Russian state and public universities dominate over private HEIs, not only in budget financing but also in the competition for educational services and research. The example of the Russian Academic Excellence Project shows how the provision of an artificial competitive advantage to certain universities negatively affects the intensity of competition and the overall competitiveness of other Russian HEIs.

Academic Excellence Programs give excellence statuses to universities that are already strong and advantaged, and described as "elite institutions" or "leading universities". Thus, Academic Excellence Initiatives become universities' status makers, allowing the strong ones to become stronger. Academic Excellence Initiatives in higher education can be successfully used to increase the most critical performance indicators adopted by commercial ratings (THE, QS, and SJTU ARWU) of at least several HEIs.

Additionally, it is worth considering the ratio of academic excellence and competitiveness in higher education in terms of performance indicators of universities' educational and scientific activities. HEIs participating in Project 5-100 take into account the following compulsory performance indicators under the regulatory legal acts of the Ministry of Science and Higher Education of the Russian Federation:

- Publications in Web of Science and Scopus databases, excluding duplication; 
- Average citation index per 1 faculty, calculated from the total number of publications in Web of Science and Scopus databases;

- Share of international teachers, lecturers, and researchers;

- Share of international students (including students and postgraduates from the Commonwealth of Independent States);

- Average Unified State Exam score of full-time students admitted to bachelor's and specialist programs whose tuition is covered by the government;

- Share of students enrolled in master's or postgraduate programs with bachelor's, specialist's, or master's diploma from other HEIs;

- Volume of scientific research per 1 faculty;

- Share of non-budgetary sources in a university's income structure;

Of the above indicators, the number of scientific publications and the research volume reflect the effectiveness of universities' academic activities. The remaining indicators characterize the resource potential of a university's competitive activity. It can be easily noted that there is a bias in favor of indicators evaluating the resource component of university competitiveness versus indicators reflecting the performance. The quality of educational activities and competitiveness in regional educational markets is not reflected in the system of indicators of academic excellence initiatives.

Russia has also implemented the concept of a supporting university - a regional HEI that provides personnel training for the basic sectors of the economy and social sphere of a region. In an effort to ensure the regional competitiveness of Russian universities, the government strengthened the academic excellence program by developing supporting universities within the federal project Young Professionals.

The multifaceted nature of university competitiveness allows the use of particular control indicators of development programs and academic excellence projects to assess certain types of university competitiveness, in particular, through targeted influence on the factors found in this study. Thus, the minimum requirements for the education quality and regional competitiveness can be reflected in the following targeted indicators of supporting universities (Budzinskaya, 2018; Thurman \& Efimova, 2014; Gazizova et al., 2016):

- Share of income from educational activities funded by private individuals and organizations;

- Number of agreements;

- Graduates' average grades;

- Share of graduates employed after graduation;

- Graduates' salaries.

The above indicators were also used in this study as proposed factors for assessing the university competitiveness.

Currently applied approaches in the Russian higher education system do not have a single criteria basis. These days, in Russia, a single competitive educational environment was formed. Universities of different statuses and forms of ownership 
compete for talented students, teachers, and better financing of their activities. Meanwhile, to solve the fiscal and administrative tasks of allocating budgetary funding for higher education, the Ministry of Science and Higher Education of the Russian Federation has created the artificial separation of universities by status. Such administrative separation does not contribute to the formation of consistent ideas according to which universities and educational programs are deemed competitive and able to outrank other regional, national, and international HEIs.

From the perspective of the Western economic paradigm, the issue of a university's competitiveness is quite transparent. It has clear measuring instruments, evaluation criteria, and management strategies (Gunn, 2018). However, the question about the content of the university competitiveness concept outside the framework of market competition remains contentious. Researchers are still debating whether the understanding of a university's competitiveness beyond a competitive approach is valid. At present, the competitiveness of a Russian HEI is beginning to be understood in the context of its ability to attract more sources of financing for its educational and scientific activities, regardless of regional market competition for paid educational services and research.

Nowadays, the higher education market in Russia is characterized by the situation when top-ranked HEIs, whose practices are taken as an example to determine academic excellence, have developed competitiveness in cooperation with government bodies and public organizations. This approach accentuates one factor identified by the current study (governmental support), and practically excludes the impact of the remaining ones, which negatively affects the possibilities of competition with world universities. It cannot be argued that such a state of affairs is not typical for European or Asian countries (Sitnicki, 2018; Paul \& Long, 2016; Budzinskaya, 2018). This situation is also reflected in the present study in the form of administrative workers' overestimation of state factors in increasing the academic excellence of HEIs. Nevertheless, the question remains open whether it is possible to assess and develop competitiveness of less efficient universities accurately.

The importance of state participation in the formation of competitiveness and academic excellence was rated as very low by the respondents of this research. Thus, a more indepth and thorough examination is required toward the negative effects of academic excellence initiatives on the national higher education system due to the creation of artificial competitive advantages for specific HEIs.

As a result of the implementation of academic excellence initiatives and earlier reforms in higher education (consolidation of federal universities and the separation of research and supporting universities from other HEIs), the status stratification of Russian universities occurs, and vertical differentiation of educational services in national and local markets intensifies. In most European and rapidly developing Asian countries, this does not happen due to deeper integration into global processes of education transformation (Paul \& Long, 2016; Froumin \& Lisyutkin, 2018). Competition is a natural element of any university life as well as support from the state, which is carried out as part of special programs. It is believed that the creation of artificial competitive 
advantages for several universities leads to a decrease in the competitiveness of the entire educational system (Fumasoli, 2017; Gunn, 2018). Thus, future investigation should focus on how to measure and compare the positive and negative effects of the academic excellence initiatives on the performance of Russian higher education system.

According to many researchers attempts to apply the provisions of the constructive theory of competition to determine university competitiveness factors remain problematic (Pucciarelli \& Kaplan, 2016; Rubin, 2017b; Musselin, 2018). Traditionally, such factors include the share of regional research and education markets and the share of income from non-budgetary sources. However, the determination of university competitiveness factors is possible if one applies theoretical separation toward the constructive theory of competition (differentiation of competition for resources, results, and excellence of educational processes). Therefore, the resources' competitiveness can be assessed by the number of applicants and their average grades, the number of scientific and pedagogical workers and their academic degree, salary level, and material support (Gunn, 2018). In a modern economy, access to all of these resources can be organized or facilitated thanks to the low-cost online technologies. Competitiveness in educational activities results can be assessed by means of university income from educational activities, the number of graduates, graduates' average grades, the share of graduates employed after graduation, and their average salaries. Alongside this, competitiveness of scientific activity can be estimated in the income from scientific research, the number of orders from companies interested in research, the research investment, and the number of university workers involved in the research process (Antony, 2018). Unfortunately, in assessing a HEI's competitiveness, many studies neglect using approaches provided by the modern constructive theory of competition that differentiates competition for resources, results, and excellence of educational processes and actions (Rubin, 2017b).

\section{CONCLUSION}

This study was conducted to clarify factors of higher education competitiveness and academic excellence, taking into account emerging technologies in learning. The objective of the present research was to provide practical support to further studies in this field. The examination enrolled 361 teachers, researchers, and administrative workers from 172 universities of the Russian Federation. Based on the variations in respondents' assessments of different groups of factors, it was confirmed that the categories of competitiveness and academic excellence were not recognized as identical. In terms of the results of this study, competitiveness was determined as a prerequisite for achieving academic excellence. The determining factor for achieving competitiveness could well be determined by online technologies and m-learning technologies.

This research revealed that the Russian approach to managing HEI competitiveness, stipulated by regulatory acts of state authorities, basically ignores the real competitiveness parameters, such as the decisive role of learning technologies and turns out to be just a set of obligatory actions for becoming a WCU. In the course of the study, the following factors received the most uniform assessment among the respondents: graduates' salaries (4.08, 3.89, 4.16 in 3 respondent groups), the number of 
international students $(4.01,4.44,4.56)$, the number of publications in indexed databases $(3.69,4.63,3.81)$, and the amount of extrabudgetary income of universities from their scientific and other activities $(4.12,4.27,4.56)$. The implication of this study lies in the identification of a number of practically significant factors in improving the academic excellence and competitiveness. Taking into account these factors should improve the positions of Russian HEIs and HEIs of developing countries in international ratings. Further research requires checking the results obtained for universities in other regions and identifying correlations and differences in the factors of academic excellence and competitiveness.

The results of this study can be used by universities for the holistic formation of their development policies taking into account web-based learning and by administrative bodies in the decision-making process in the higher education field.

\section{REFERENCES}

Antony, J. (2018). A conceptual Lean Six Sigma framework for quality excellence in higher education institutions. International Journal of Quality \& Reliability Management, 35(4), 857-874.

Avralev, N., \& Efimova, I. (2014). Global university rankings as indicators of the implementation of the integration process and competitive tool in the context of globalization of higher education. Life Science Journal, 11(10), 648-652.

Beerkens, M. (2018). Evidence-based policy and higher education quality assurance: progress, pitfalls and promise. European Journal of Higher Education, 8(3), 272-287.

Benneworth, P., Zeeman, N., Pinheiro, R., \& Karlsen, J. (2017). National higher education policies challenging universities' regional engagement activities, EKONOMIAZ. Revista vasca de Economía, 92(2), 112-139.

Bragin, L., Selyanskaya, G., \& Stukalova, I. (2014). Competitiveness assessment of Russian universities under the conditions of globalization. Life Science Journal, 11(12), 268-273.

Budzinskaya, O. (2018). Competitiveness of Russian Education in the World Educational Environment. Astra Salvensis, 6(11), 565-576.

French, A. (2017). Contextualising excellence in higher education teaching: Understanding the policy landscape. In A. French, \& M. O'Leary (Eds.), Teaching excellence in higher education (pp. 5-38). Bingley, UK: Emerald Publishing.

Froumin, I., \& Lisyutkin, M. (2018). State and world-class universities: Seeking a balance between international competitiveness, local and national relevance. In Y. Wu, Q. Wang, \& N. Cai Liu (Eds.), World-Class Universities: Towards a Global Common Good and Seeking National and Institutional Contributions (pp. 243-260). Rotterdam:Brill Sense. 
Fumasoli, T. (2017). The paths towards excellence of European Flagship universities.

University Management: Practice and Analysis, 21(2).

DOI: 10.15826/umpa.2017.02.014

Gazizova, A. I., Panfilova, V. M., \& Makarova, O. A. (2016). Towards Excellence in Russian Higher Education Institutions. International Journal of Humanities and Cultural Studies, 1(1), 580-587.

Gourlay, L., \& Stevenson, J. (2017). Teaching excellence in higher education: Critical perspectives. Teaching in Higher Education, 22(4), 391-395.

Guerrero, M., Urbano, D., \& Fayolle, A. (2016). Entrepreneurial activity and regional competitiveness: evidence from European entrepreneurial universities. The Journal of Technology Transfer, 41(1), 105-131.

Guilbault, M. (2016). Students as customers in higher education: reframing the debate. Journal of Marketing for Higher Education, 26(2), 132-142.

Gunn, A. (2018). Metrics and methodologies for measuring teaching quality in higher education: developing the Teaching Excellence Framework (TEF). Educational Review, 70(2), 129-148.

Guskov, A. E., Kosyakov, D. V., \& Selivanova, I. V. (2018). Boosting research productivity in top Russian universities: the circumstances of breakthrough. Scientometrics, 117, 1053-1080.

Harvey, L. (2020). Analytic Quality Glossary. Quality Research International. Retrieved 16 August, 2020 from http://www.qualityresearchinternational.com/glossary/

Hemsley-Brown, J., Melewar, T. C., \& Nguyen, B. (2016). Exploring Brand Identity, Meaning, Image, and Reputation (BIMIR) in Higher Education: A Special Section, Journal of Business Research, 69(8), 3019-3022.

Komotar, M. H. (2020). Discourses on quality and quality assurance in higher education from the perspective of global university rankings. Quality Assurance in Education.

Lukovics, M., \& Zuti, B. (2013). Successful universities towards the improvement of regional competitiveness: 'fourth generation' universities. In Proceedings of the European Regional Science Association (ERSA) 53th Congress „Regional Integration: Europe, the Mediterranean and the World economy, At Palermo. Retrieved 16 August, 2020 from https://www.researchgate.net/publication/260554225_Successful_universities_towards_t he_improvement_of_regional_competitiveness_Fourth_Generation_universities

Maket, L. (2017). Resource rarity: The public/private universities sustainable competitiveness strategy. American Based Research Journal, 6(2), 6-15.

Miccedu. (2020). Characteristic of the Higher Education System in the Russian Federation. Miccedu. Retrieved 16 August, 2020 from http://indicators.miccedu.ru/monitoring/?m=vpo 
Musselin, C. (2018). New forms of competition in higher education. Socio-Economic Review, 16(3), 657-683.

Nabi, G., Liñán, F., Fayolle, A., Krueger, N., \& Walmsley, A. (2017). The impact of entrepreneurship education in higher education: A systematic review and research agenda. Academy of Management Learning \& Education, 16(2), 277-299.

Naser, S. S. A., Al Shobaki, M. J., \& Amuna, Y. M. A. (2016). Knowledge Management Maturity in Universities and its Impact on Performance Excellence" Comparative study". Journal of Scientific and Engineering Research, 3(4), 4-14.

Parakhina, V., Godina, O., Boris, O., \& Ushvitsky, L. (2017). Strategic management in universities as a factor of their global competitiveness. International Journal of Educational Management, 31(1), 62-75.

Paul, A. M., \& Long, V. (2016). Human-capital strategies to build world-class research universities in Asia. In M.-H. Chou, I. Kamola, \& T. Pietsch (Eds.), The transnational politics of higher education: Contesting the global/transforming the local (pp. 130-155) London: Routledge.

Project 5-100. (2020). Government approves subsidies to universities participating in Project 5-100 for 2020. Russian Academic Excellence Project 5-100. Retrieved 16 August, 2020 from https://5top100.ru/news/118620/

Pucciarelli, F., \& Kaplan, A. (2016). Competition and strategy in higher education: Managing complexity and uncertainty. Business Horizons, 59(3), 311-320.

Redondo, R. P., Cárdenas, M. J., Daza, B. C. O., Cataño, C. L. M., \& Hernandez, P. H. G. (2018). Integrated Management Systems as a Tool for Strengthening and Competitiveness in Higher Education Institutions in Colombia. Contemporary Engineering Sciences, 11(43), 2135-2147.

Ruben, B. D., \& Gigliotti, R. A. (2019). The excellence in higher education model: A Baldrige-based tool for organizational assessment and improvement for colleges and universities. Global Business and Organizational Excellence, 38(4), 26-37.

Rubin, Y. B. (2017a). Competition in the Russian Education: Theory and Contradictory Reality. University management: practice and analysis, 5, 17-30.

Rubin, Y. B. (2017b). About the Constructive Theory of Competition in Entrepreneurship. Journal of Modern Competition, 5(65), 114-129.

Salmi, J. (2016b). Excellence strategies and world class universities. In E. Hazelkorn (Eds.), Global rankings and the geopolitics of higher education (pp. 216-243). Abingdon: Routledge.

Salmi, J. (2016a). Excellence strategies and the creation of world-class universities. In N. C. Liu, Y. Cheng, \& Q. Wang (Eds.), Matching Visibility and Performance (pp. 1548). Rotterdam: Brill Sense. 
Satsyk, V. (2018). Global competitiveness of universities. In J. Valsiner, A. Lutsenko, \& A. Antoniouk (Eds.), Sustainable Futures for Higher Education (pp. 115-122) Cham: Springer.

Secundo, G., De Beer, C., Schutte, C. S., \& Passiante, G. (2017). Mobilising intellectual capital to improve European universities' competitiveness. Journal of Intellectual Capital, 18(3), 607-324.

Sitnicki, M. (2018). Exploration of the role of business schools in the development of world-class research universities. Technology audit and production reserves, 1(5), 3645 .

Tasopoulou, K., \& Tsiotras, G. (2017). Benchmarking towards excellence in higher education. Benchmarking: An International Journal, 24(3), 617-634.

Tatiana, F. (2017). The paths towards excellence of European flagship universities. University Management: Practice and Analysis, $21(2$ (108)), 9-10. DOI 10.15826/umpa.2017.02.014

The EFQM Model (2020). Driving organisational change and performance improvement. The European Foundation for Quality Management. Retrieved 16 August, 2020 from https://www.efqm.org/

Thurman, P. W., \& Efimova, I. (2014). Use of rankings to improve global competitiveness of Russian's higher education institutions and technology exports. Life Science Journal, 11(11), 285-289.

Vasilev, A. (2017) Competitiveness of the university in competition theory and Russian legislation. Journal of Modern Competition, 11(6), 122-134.

Visvizi, A., Lytras, M. D., \& Daniela, L. (Eds.) (2018). The future of innovation and technology in education: policies and practices for teaching and learning excellence. Bingley, U.K.: Emerald Publishing.

Wood, M., \& Su, F. (2017). What makes an excellent lecturer? Academics' perspectives on the discourse of 'teaching excellence' in higher education. Teaching in higher education, 22(4), 451-466.

Yousaf, R., \& Schmiede, R. (2017). Barriers to women's representation in academic excellence and positions of power. Asian Journal of German and European Studies, 2(1), 1-13. 